\title{
DIFFERENCES IN INTRAMAMMARY PATHOGENICITY OF FOUR STRAINS OF STREPTOCOCCUS DYSGALACTIAE
}

\author{
T. M. Higgs, F. K. Neave and A. J. Bramley \\ National Institute for Research in Dairying, Shinfield, Reading RG2 9AT
}

STREPTOCOCCUS DYSGALACTIAE has long been recognised as an udder pathogen. It was first described by Diernhofer (1932) and subsequently classified as a group-C streptococcus by Lancefield (1933). It can be found in various extramammary sites, including the vagina (Francis, 1941) and tonsils (Daleel and Frost, 1967) of adult cattle, but the significance of these sites as reservoirs of infection in a herd is not known. Udder infection with $S$. dysgalactiae is generally less frequent than with either $S$. agalactiae or $S$. uberis (Slanetz and Naghski, 1940). Results from 32 herds in the United Kingdom showed that $2.9 \%$ of cows were infected with $S$. dysgalactiae compared with $4.0 \%$ and $4.4 \%$ for S. agalactiae and S. uberis respectively (Wilson and Kingwill, 1975). McDonald and McDonald (1976) found that 41 of $455(9 \%)$ streptococcal isolates from infected udders were $S$. dysgalactiae compared with $7(1.5 \%)$ for $S$. agalactiae and $257(56 \%)$ for $S$. uberis.

Experimental infections of goats and cattle with $S$. dysgalactiae have been successful (Edwards, 1932; Holman, Pattison and Gordon, 1952; Pattison and Smith, 1953) but we are not aware of published results comparing the infectivity of strains. It was partly for this reason and partly to identify an infective strain for milking-machine studies that this work was done.

The ability of streptococci to form chains means that the number of colony-forming units per unit volume could be a misleading indication of the number of viable organisms in a challenge volume, particularly if one of the strains tended to produce long chains whilst others produced short chains in the growth conditions used. To investigate the possible effects of this factor, strains for infection studies were compared before and after treatment that would disrupt chains.

\section{MATERIALS AND METHODS}

Strains of S. dysgalactiae. Strains were isolated as follows: strain CE 127 in 1969 from a clinical case of mastitis on Farm CE, strain BE63 in 1968 from a clinical case of mastitis on Farm BE, strain BC93 in 1970 from a clinical case of mastitis on Farm BC, strain 401/10 from mastitic milk in 1970 by the Veterinary Investigation Centre, Coley Park, Reading. Strains CE127 and BC93 are deposited in the National Collection of Dairy Organisms and numbered 2043 and 2023 respectively. Cultures were grown on nutrient-agar slopes containing $10 \%(\mathrm{v} / \mathrm{v})$ calf blood at $37^{\circ} \mathrm{C}$ for $18 \mathrm{~h}$. The slopes were stored at $4^{\circ} \mathrm{C}$ and subcultured at $2-3$-month 
intervals. All four strains showed the typical biochemical reactions of S. dysgalactiae (Cowan and Steel, 1974) but differed in their abilities to produce acid from sorbitol; strains BC93 and 401/10 were sorbitol positive whilst CE127 and BE63 were sorbitol negative. From all four strains, an $\mathrm{HCl}(0 \cdot 2 \mathrm{~N})$ extract gave a precipitin reaction with Lancefield Group-C Streptococcal Antiserum (Burroughs Wellcome, Beckenham, Kent).

Cultures of $S$. dysgalactiae for udder challenge. The organisms were subcultured on nutrientagar plates containing 7-8\% (v/v) calf blood and $0.1 \%$ aesculin (ABA). The plates were incubated at $37^{\circ} \mathrm{C}$ for $c .40 \mathrm{~h}$ and several typical colonies were transferred to $10 \mathrm{ml}$ of litmus milk which was incubated at $37^{\circ} \mathrm{C}$ for $17 \mathrm{~h}$. After incubation the litmus-milk cultures were cooled to $4^{\circ} \mathrm{C}$ and divided into two equal parts; one part was ultrasonically treated for $1 \mathrm{~min}$. (Soniprobe, Dawes Ltd, London) and the other part left untreated. Earlier tests had shown that this treatment increased the percentage of single or diplococcal units in a culture of strain CE127 from $66 \%$ to $100 \%$. Samples of sonicated and untreated culture were diluted in half-strength nutrient broth ( $\left.\frac{1}{2} \mathrm{NB}\right)$ (Oxoid Broth No. 2) and five $0 \cdot 1-\mathrm{ml}$ volumes of a $10^{6}$ dilution were plated on ABA to determine the number of colony-forming units $/ \mathrm{ml}$ (c.f.u./ml). The increases in c.f.u./ml resulting from ultrasonic treatment are shown in table $I$. The undiluted cultures were

TABLE I

Effect of ultrasonic treatment for 1 min. on the number of colony-forming units of Streptococcus dysgalactiae

\begin{tabular}{|c|c|c|c|}
\hline \multirow[b]{2}{*}{$\begin{array}{l}\text { S. dysgalactiae } \\
\text { strain no. }\end{array}$} & \multicolumn{2}{|c|}{$\begin{array}{l}\text { Colony-forming units } \\
\left(10^{6}\right) / \mathrm{ml} \text { of culture }\end{array}$} & \multirow[b]{2}{*}{ (b) $\div$ (a) } \\
\hline & $\begin{array}{l}\text { before } \\
\text { ultrasonic } \\
\text { treatment } \\
\text { (a) }\end{array}$ & $\begin{array}{l}\text { after } \\
\text { ultrasonic } \\
\text { treatment } \\
\text { (b) }\end{array}$ & \\
\hline $\begin{array}{l}\text { BC93 } \\
\text { CE127 } \\
\text { BE63 } \\
401 / 10\end{array}$ & $\begin{array}{r}620 \\
1080 \\
947 \\
260\end{array}$ & $\begin{array}{r}1100 \\
1700 \\
1370 \\
633\end{array}$ & $\begin{array}{l}1.8 \\
1.6 \\
1.4 \\
2.4\end{array}$ \\
\hline
\end{tabular}

stored overnight at $4^{\circ} \mathrm{C}$ and then diluted to contain about 40 c.f.u. $/ \mathrm{ml}$; the diluted suspensions were introduced into the udder sinus.

Experimental animals. Sixteen lactating Friesian cows were used. They were housed in cubicles on sawdust bedding and milked twice daily, at 06.00 and 14.30 hours, in a six-unit tandem milking parlour. Before milking, udders were washed and dried; after milking, teats were dipped in a hypochlorite solution containing $4 \%$ available chlorine. The milking clusters were pasteurised by the circulation of water at $c .80^{\circ} \mathrm{C}$ for about $10 \mathrm{~s}$ between milking of each cow. Quarter foremilk samples were collected on two occasions during the 7 days before challenge to establish the level of infection at the start of the experiment. Of the 64 quarters, 61 were free from bacterial infection during this period. Of the remaining three quarters, two were excreting coagulase-negative staphylococci while the third was infected with Corynebacterium ulcerans. The distribution of these infected quarters is shown in the footnotes to tables II and III. Of the 16 animals, 12 were in their first lactation and the oldest cow was in its sixth lactation. Ten cows had calved not more than 6 weeks earlier but one animal had been in milk for 72 weeks.

Experimental design. Cows nos. 1-8 were challenged with suspension (U) prepared by ultrasonic treatment whilst nos. 9-16 were challenged with the untreated control suspension (C). Each cow was infused in all four quarters, each quarter being challenged with a different strain according to a latin-square design.

Collection and examination of quarter foremilk samples. The methods used for the aseptic collection and examination of quarter foremilk samples have been described by Bramley (1976). Samples were taken on the day of infusion, $1,1 \frac{1}{2}, 2$ and 5 days after infusion and then at frequent intervals up to a maximum of 20 days. All samples were examined for bacteria, clots and 
discoloration, and by the modified Whiteside test as an indirect measure of the somatic-cell content (Murphy and Hanson, 1941).

Infusion of the quarters. Infusions were done after an afternoon milking. When the cow entered the parlour, samples were taken from each quarter and the cow was milked. A sample of strippings milk was then collected and the teat orifice scrubbed for $15-20 \mathrm{~s}$ with $70 \%$ ethyl alcohol. After cleaning of the teat, $0.25 \mathrm{ml}$ of the bacterial suspension was infused through the teat duct into the teat sinus as described by Bramley (1976). The sample of stripping milk was examined for somatic cells by the microscopic method of Prescott and Breed (1910). Within 20 min. of infusion, $0.25 \mathrm{ml}$ of each infusion suspension was plated in triplicate on ABA for calculation of the number of organisms infused.

Detection of clinical signs. A careful examination of the foremilk was made with a strip cup before each milking and clots were recorded on a scale from 1 to 4 (grade 1 indicating one or two small clots and grade 4 severe clotting). Milk samples were also examined for clots after standing overnight at $4^{\circ} \mathrm{C}$. After milking, the udder was palpated to detect hardness, swelling or tenderness of the quarters.

Growth of $S$. dysgalactiae in raw milk. Subcultures of $S$. dysgalactiae were made from nutrient blood agar in a medium containing 30 parts of yeast dextrose litmus milk and 70 parts of dextrose Lemco (Oxoid) broth; these were incubated at $37^{\circ} \mathrm{C}$ for $5 \mathrm{~h}$, cooled rapidly in iced water, stored at $4^{\circ} \mathrm{C}$ and then diluted in $\frac{1}{2} \mathrm{NB}$ to give $c .40 \mathrm{c.f} . \mathrm{u}$. $/ \mathrm{ml}$. Whole milk was obtained by aseptic cannulation of three cows free from intramammary infection. The milk was pooled and dispensed into sterile plugged test tubes in $10-\mathrm{ml}$ portions. After warming to $37^{\circ} \mathrm{C}$ the tubes were inoculated with $1 \mathrm{ml}$ ( $40 \mathrm{c}$.f.u.) of the diluted culture and incubated in a water bath at $37^{\circ} \mathrm{C}$. Samples were taken after 5- and 18-h incubation for colony counting.

\section{RESULTS}

Comparison of the pathogenicity of four strains of S. dysgalactiae. The results of challenge with each strain are shown in table II. Of the 36 infections, 35 were detected within 5 days of challenge; and one quarter challenged with strain BC93 became infected after 14 days. "Infection" in this context has been defined as the presence of 20 or more of the challenge organisms $/ \mathrm{ml}$ of milk - the minimum number detectable by the technique used-with an increase in Whiteside score of two grades or distinct clinical signs of mastitis on at least one occasion. Although strain CE127 infected all 16 challenged quarters, strain 401/10 was reisolated only once after infusion and did not produce definite clinical disturbance or increase in Whiteside score. Clots were found once in one quarter after challenge with strain $401 / 10$ but this quarter had a pre-infusion strippings cell count of $>14 \times 10^{6} / \mathrm{ml}$ that may have been related to the subsequent clinical disturbance. Pathogens were not isolated in the period immediately before or after challenge. Strains BE63 and BC93 yielded similar results, infecting 10 quarters.

Analysis of variance of mean infection scores showed strain CE127 to be significantly more infective than strains BC93 and BE63 $(p=0.01)$, and these three strains to be more infective than strain $401 / 10(p=0.005)$. Differences between the infectivity of control and ultrasonicated suspensions were not significant. The small differences between the viable counts of the treated and the untreated suspensions (table I) indicated that little chaining had occurred in the untreated suspension.

Relationship between pre-challenge milk cell count and infection. Table III shows the proportion of challenged quarters that became infected in relation to 


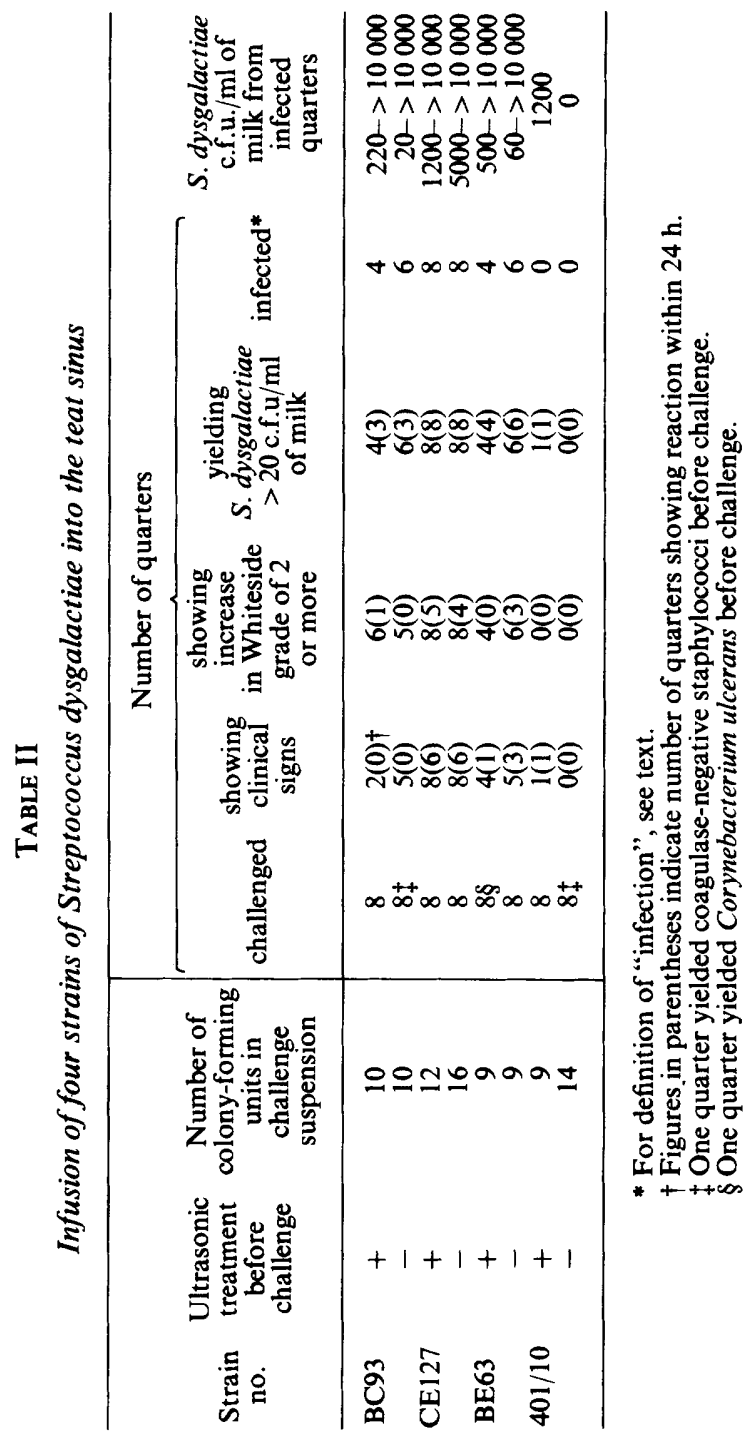


TABLE III

Relationship between pre-challenge milk cell count of strippings milk and outcome of challenge with Streptococcus dysgalactiae

\begin{tabular}{l|ccc}
\hline $\begin{array}{c}\text { Strain } \\
\text { no. }\end{array}$ & $\begin{array}{c}\text { Number of quarters infected } / \text { number } \\
\text { of quarters challenged that had } \\
\text { pre-challenge cell counts }\end{array}$ \\
\cline { 2 - 4 } & $\left(10^{3} / \mathrm{ml}\right)$ of \\
\hline 250 & $250-500$ & $>500$ \\
\hline CE127 & $7 / 7$ & $6 / 6$ & $3 / 3$ \\
BC93 & $4 / 4$ & $3 / 6$ & $3 / 6^{*}$ \\
BE63 & $6 / 6$ & $2 / 6$ & $2 / 4 \dagger$ \\
$401 / 10$ & $0 / 5$ & $0 / 4$ & $0 / 7^{*}$ \\
\hline Totals & $17 / 22$ & $11 / 22$ & $8 / 20$ \\
\hline
\end{tabular}

* One quarter yielded coagulase-negative staphylococci before challenge. † One quarter yielded Corynebacterium ulcerans before challenge.

the pre-challenge strippings cell count. Strain CE127 infected all the challenged quarters, and strain $401 / 10$ none, irrespective of initial cell count. But for the other two strains, quarters with cell counts of less than $250 \times 10^{3} / \mathrm{ml}$ were significantly more susceptible to these strains than quarters with counts greater than this number $(p=0.01)$. The three quarters that were already infected at the time of challenge had cell counts ranging from $600 \times 10^{3}$ to $8000 \times 10^{3} / \mathrm{ml}$ and none became infected with the test strains.

Growth of $S$. dysgalactiae in milk. All four strains grew in raw milk and the small differences detected between them (table IV) did not correlate with their infectivity.

TABLE IV

Growth of four strains of Streptococcus dysgalactiae in raw milk

\begin{tabular}{|c|c|c|c|}
\hline \multirow{2}{*}{$\begin{array}{l}\text { Strain } \\
\text { no. }\end{array}$} & \multicolumn{3}{|c|}{$\begin{array}{l}\text { Colony forming units } / \mathrm{ml} \text { of } \\
\text { milk* after incubation at } 37^{\circ} \mathrm{C} \text { for }\end{array}$} \\
\hline & $0 \mathrm{~h}$ & $5 \mathrm{~h}$ & $18 \mathrm{~h}$ \\
\hline $\begin{array}{l}\text { CE127 } \\
401 / 10 \\
\text { BC93 } \\
\text { BE63 }\end{array}$ & $\begin{array}{l}23 \\
68 \\
24 \\
68\end{array}$ & $\begin{array}{r}45 \times 10^{3} \\
9.5 \times 10^{3} \\
5.3 \times 10^{3} \\
18.4 \times 10^{3}\end{array}$ & $\begin{array}{r}35 \times 10^{6} \\
16.5 \times 10^{6} \\
6.7 \times 10^{6} \\
34 \times 10^{6}\end{array}$ \\
\hline
\end{tabular}

* Mean of three counts

\section{Discussion}

This study shows clearly that there are differences in intramammary infectivity between strains of $S$. dysgalactiae. It also emphasises the susceptibility of the udder to disease because infection always followed the introduction of 12 or more cells of $S$. dysgalactiae strain CE127 into the gland after milking. 
The extent to which differences in infectivity between strains of a pathogen influence rates of infection in commercial dairy herds is unclear. Dodd and Neave (1970) reported that herds with high rates of streptococcal udder disease also tended to have high rates due to other pathogens such as Staphylococcus aureus. This observation suggests that, in field conditions, the strain of micro-organism is less important than some other factor(s) influencing the incidence of udder disease.

A successful pathogen, having gained entrance to the udder, must be able to multiply in milk and withstand the flushing-out effect of milking. All four of the strains of $S$. dysgalactiae that we studied multiplied in raw milk but the small differences detected between strains in their rates of growth did not correlate well with the large differences in infectivity. We were able to show a significant relationship between the milk cell count at the time of infusion and susceptibility to infection, supporting other data which indicate that increased leucocyte numbers enhance the resistance of quarters to infection. (Schalm, Lasmanis and Carroll, 1964; Bramley, 1976). Frost (1975) suggested that attachment of bacteria to the epithelial surfaces of the mammary gland was an important initial stage in mastitis. Further study led Frost, Wanasinghe and Woolcock (1977) to propose that differences in infectivity might be related to the ability of strains to adhere to ductular epithelium. They included strains 401/10 and CE127 (termed 137 and 138, respectively) in their study of adhesion and found that strain CE127 gave the highest adherence index of any of the strains of $S$. dysgalactiae they tested. However, the adherence index was low when compared with that of Staph. aureus and most strains of $S$. agalactiae.

This work adds to the accumulating evidence that even when some strains penetrate the teat duct they rarely cause disease. Carroll et al. (1973) showed that strains of coliform bacteria that were sensitive to the bactericidal action of bovine serum were avirulent for the lactating udder. Garvie and Bramley (1979) found differences in infectivity between strains of $S$. bovis. In the present study the differences between the strains of $S$. dysgalactiae in the severity of the infection that they caused suggest that, after infusion, some strains were rapidly eliminated without causing a major inflammatory response. The elimination of serum-sensitive strains of Escherichia coli can also occur without measurable inflammation (Anderson, Burrows and Bramley, 1977). Although many antibacterial mechanisms of milk have been described (Reiter and Bramley, 1975) our knowledge of their importance in influencing rates of udder disease is limited.

\section{SUMMARY}

The intramammary pathogenicity of four strains of Streptococcus dysgalactiae was measured by infusion of small numbers of bacteria (8-16 colonyforming units) into the teat sinus after milking. Significant differences in the infectivity of strains were detected. 


\section{REFERENCES}

Anderson, J. C., Burrows, M. R. And Bramley, A. J. 1977. Bacterial adherence in mastitis caused by Escherichia coli. Vet. Path., 14,618.

Bramley, A. J. 1976. Variations in the susceptibility of lactating and non-lactating bovine udders to infection when infused with Escherichia coli. J. Dairy Res., 43, 205.

Carroll, E. J., Jain, N. C., Schalm, O. W. and Lasmanis, J. 1973. Experimentally induced coliform mastitis: inoculation of udders with serum-sensitive and serum-resistant organisms. Am.J. vet. Res., 34, 1143.

Cowan, S. T. and SteEL, K. J. 1974. Manual for the identification of medical bacteria, 2nd ed. Cambridge University Press: Cambridge, p. 58.

Daleel, E. E. AND Frost, A. J. 1967. Some observations on the bacterial flora of the bovine tonsil. Br. vet. J., 123, 232.

DieRnHOFER, K. 1932. Äsculinbouillon als Hilfsmittel für die Differenzierung von Euter-und Milchstreptokokken bei Massenuntersuchungen. Milchwirtschaftliche Forschungen, 13, 368.

Dodd, F. H. and Neave, F. K. 1970. Mastitis control. Vet. A., 11, 21.

EDWARDS, S. J. 1932. Studies on bovine mastitis. VI. The non-haemolytic streptococci of bovine mastitis and their relationship to certain saprophytic streptococci from cattle. $J$. comp. Path. Ther., 45, 43.

FranCIS, J. 1941. A bacteriological examination of bovine tonsils and vaginas. Vet. J., 97, 243.

Frost, A. J. 1975. Selective adhesion of microorganisms to the ductular epithelium of the bovine mammary gland. Infect. Immun., 12, 1154.

Frost, A. J., Wanasinghe, D. D. AND WoOLCOCK, J. B. 1977. Some factors affecting selective adherence of microorganisms in the bovine mammary gland. Infect. Immun., 15, 245.

Garvie, E. I. AND Bramley, A. J. 1979. Streptococcus bovis - an approach to its classification and its importance as a cause of bovine mastitis. J. appl. Bact., 46, 557.

Holman, H. H., Pattison, I. H. and Gordon, W. S. 1952. Studies on experimental streptococcal mastitis. VII. Immunological studies in goats. J. comp. Path., 62, 196.

LANCEFIELD, R. C. 1933. A serological differentiation of human and other groups of hemolytic streptococci. J. exp. Med., 57, 571.

MCDonald, T. J. AND MCDonald, J. S. 1976. Streptococci isolated from bovine intramammary infections. Am. J. vet. Res., 37, 377.

MurPhy, J. M. And Hanson, J. H. 1941. A modified Whiteside test for the detection of chronic bovine mastitis. Cornell Vet., 31, 47.

Pattison, I. H. And Smith, I. M. 1953. The histology of experimental Streptococcus dysgalactiae mastitis in goats. J. Path. Bact., 66, 247.

Prescott, S. C. AND BReEd, R. S. 1910. The determination of the number of body cells in milk by a direct method. J. infect. Dis., 7, 632 .

Reiter, B. AND Bramley, A. J. 1975. Defence mechanisms of the udder and their relevance to mastitis control. In Proc. seminar on mastitis control. Annual Bulletin no. 85, International Dairy Fedn., Brussels, p. 21.

Schalm, O. W., Lasmanis, J. and Carroll, E. J. 1964. Pathogenesis of experimental coliform (Aerobacter aerogenes) mastitis in cattle. Am.J. vet. Res., 25, 75.

Slanetz, L. W. AND NaGhSKI, J. 1940. Studies on streptococci of bovine mastitis. J. infect. Dis., 66, 80 .

Wilson, C. D. and Kingwill, R. G. 1975. A practical mastitis control routine. In Proc. seminar on mastitis control. Annual Bulletin no 85, International Dairy Fedn., Brussels, p. 422 . 